\title{
THE DIRECT MEASUREMENT OF THE EXTRACELLULAR PHASE OF TISSUES ${ }^{1,2}$
}

\author{
By GEORGE NICHOLS, JR., ${ }^{8}$ NANCY NICHOLS, WILLIAM B. WEIL, 4 AND \\ WILLIAM M. WALLACE \\ (From the Departments of Pediatrics and Medicine, Harvard Medical School, and the Children's \\ Medical Center, Boston, Mass.)
}

(Submitted for publication May 7, 1953; accepted August 25, 1953)

Measurements of the extracellular fluid in experimental animals and man, using inulin or thiosulfate, often result in volumes of extracellular fluid that are smaller than are compatible with balance data or tissue analysis (1). The total volume of extracellular fluid, as measured by these substances, is also frequently smaller than the extracellular fluid as measured by the volume of distribution of chloride. In an attempt to explain these discrepancies, the distribution of a single injection of thiosulfate and inulin has been measured simultaneously in the whole body and in certain tissues of nephrectomized dogs, three and six hours following its administration. The resulting data have been interpreted in relation to the content of chloride, connective tissue, and water in the tissues examined. It appears that inulin penetrates connective tissue very slowly, as demonstrated by Kruh $\phi f f e r ~(2)$, and that the entire extracellular phase is not penetrated in the length of time during which inulin space measurements are usually performed. Thiosulfate has been found to be metabolized by muscle cells. However, when the volume of distribution of inulin is corrected for the amount of connective tissue unpenetrated by this substance at a given time, and compared with the volume of distribution of chloride, corrected for the higher concentration of chloride present in connective tissue water, the two volumes approach each other closely in isolated tissues, and yield identical values for the total extracellular

1 This work was supported by grant number H-748 from the National Heart Institute, U. S. Public Health Service.

2 A preliminary report of this investigation appeared in the Proceedings of the 44th Annual Meeting of the American Society for Clinical Investigation, May 1, 1952, J. Clin. Invest., 1952, 31, 652.

8 Present address: Peter Bent Brigham Hospital, Boston, Mass.

Postdoctorate Fellow, U. S. Public Health Service. fluid of the body. These results are in accord with the theory of Manery, Danielson, and Hastings (3) that the extracellular compartment of the body is a connective tissue phase diluted with an ultrafiltrate of plasma.

\section{EXPERIMENTAL PROCEDURE AND METHODS}

Eight adult mongrel dogs were nephrectomized under pentobarbital anaesthesia, which was maintained throughout the six hours of the experiment. Following nephrectomy, control specimens of blood, muscle, tendon, and skin were taken. These were obtained from the following sites: Muscle from the belly of the quadriceps muscles or from the adductor muscle of the hind leg; tendon from the Achilles or patellar tendons; and skin from the abdominal wall. Body weight was determined and 8 to 10 $\mathrm{Gm}$. of sodium thiosulfate in 50 to $60 \mathrm{ml}$. of distilled water was injected intravenously, followed by 4 to $5 \mathrm{Gm}$. of inulin in 40 to $50 \mathrm{ml}$. of distilled water. The exact amount of inulin, or thiosulfate, given was determined by specific gravity and direct analysis. Blood samples were taken hourly for six hours and biopsies of tissues were taken at three and six hours. The animals were sacrificed at the end of the experiment, and a final body weight obtained.

Each tissue specimen was divided into three parts and each part was promptly placed in a tared weighing bottle, stoppered, and weighed.

One portion was dried to constant weight at 100 to $105^{\circ}$ C., ground to a powder, and extracted at least three times with a mixture of equal parts of petroleum and ethyl ether to remove the neutral fat. The dry fat-free residue was then extracted with $0.75 \mathrm{~N} \mathrm{HNO}_{3}$, centrifuged, and aliquots of the supernatant used for the determination of sodium, potassium, and chloride (4). Sodium and potassium analyses were carried out on a flame photometer, using lithium as an internal standard (5). Chloride was measured by a micro-modification of the method of Wilson and Ball (6). All determinations were done in duplicate.

The second portion of the specimen was finely minced and transferred quantitatively to a tared $50 \mathrm{ml}$. centrifuge tube. Thirty to forty $\mathrm{ml}$. of distilled water was added and the tubes reweighed to determine the exact volume of water added. The tubes were then stoppered, agitated, and allowed to equilibrate for 18 hours in a refrigerator. Control experiments, in vitro, in which known amounts of thiosulfate were added to tissue homogenates, showed 95 to 100 per cent recovery of thiosulfate after 
18 hours incubation in the cold (7). No precautions were taken, either in the control experiments or in the experimental tissues, to prevent contamination with sulfur metabolizing bacteria. Following 18 hours incubation, the tubes were centrifuged, the supernatant removed, and duplicate aliquots analyzed for thiosulfate by a modification of the micro method of Newman, Gilman, and Philips (8).

The tissue remaining in the centrifuge tubes was analyzed for collagen and elastin by a modification of the method of Lowry, Gilligan, and Katersky (9).

The third portion of the specimen was used for the determination of inulin by the method of hot alkali digestion described by Ross and Mokotoff (10). This method adequately reduces the high inulinoid blank of tissues but necessitates the use of a form of inulin stable in hot alkali. Such a form of inulin was prepared and used in these studies (11). While such a procedure is perhaps not essential, it insures against the possibility of unequal rates of diffusion of the various forms of inulin.

Blood samples were centrifuged and the plasma separated immediately. Plasma water was measured by determining the wet and dry weights of volumes of plasma delivered from a calibrated micropyknometer. Plasma sodium and potassium were measured by internal standard flame photometry (5). Plasma chlorides were determined by the micro method of Van Slyke and Hiller (12). Thiosulfate was measured within four hours of sampling, using the micro method of Newman, Gilman, and Philips (8). Plasma inulin was determined by the method of Roe, Epstein, and Goldstein (13). All plasma determinations were carried out in duplicate.

\section{DEFINITIONS}

The terms "inulin space," "thiosulfate space," and "chloride space" are often used to denote the same volume of body water, which is then called the "extracellular water," regardless of the method used for its measurement. It will become apparent in this paper that the volumes of distribution of inulin, thiosulfate, and chloride may differ considerably from each other, and that, at best, they are only close approximations of a true, physiological, extracellular space-a space that represents the entire volume of body fluid that lies without the cells including cerebrospinal fluid water, the water in the lumen of the gastrointestinal tract, and the exocrine secretions. The following definitions are presented in order to clarify the terms used in this discussion and are illustrated in Figures 1, 4, and 5. Although the subdivisions of extracellular water defined here may not adhere to anatomical boundaries they appear to be distinct in terms of function.

Chloride space: That volume of water which contains all the chloride of a tissue or body at the concentration of a plasma ultrafiltrate.

Connective tissue corrected chloride space: The chloride space, corrected for the slightly higher chloride concentration that is present in the connective tissue water as compared to a plasma ultrafiltrate.
Inulin (or thiosulfate) space: That volume of water which contains all the inulin (or thiosulfate) in a tissue or body at a concentration equal to that in the plasma water.

Connective tissue corrected inulin (or thiosulfate) space: That volume of water of a tissue or body which is defined by the inulin (or thiosulfate) space, plus the volume of the connective tissue water which has not been penetrated by inulin (or thiosulfate)-as defined by tendon water penetration at the corresponding time.

Extracellular water: The sum of the following components :

\section{a. Plasma Water.}

b. Rapidly Equilibrating Water: The volume of water within a tissue or body which is extracellular, extravascular, not associated with collagen or elastin, and is assumed to equilibrate rapidly with the plasma concentration of substances like inulin. ${ }^{5}$

c. Connective Tissue Water: That volume of water within a tissue or whole body which is associated with the collagen and elastin of the tissue and with which substances like inulin equilibrate slowly.

\section{CALCULATION}

All calculations are based on the individual values for each dog; the averages of these results are summarized in Table I, expressed as units per kilogram of fat-free tissue or water of the fat-free tissue. For the construction of the diagrams, the values were expressed in terms of a kilogram of water of fat-free tissue.

Electrolyte concentrations in the plasma ultrafiltrates were calculated by correcting their concentration in the plasma water by a Donnan factor of 0.96 .

Chloride spaces were calculated by dividing the quantity of chloride in the tissue by the plasma ultrafiltrate concentration. Inulin or thiosulfate spaces were calculated by dividing the amount in the tissue water by the concentration in the plasma water.

The connective tissue water was calculated from the quantities of collagen and elastin in the samples, using the assumption that all body connective tissue contains the same concentration of water and electrolyte as is associated with tendon ( 90 per cent collagen). Similarly, ligamentum nuchae (81 per cent elastin) was used to calculate the water associated with elastin in other tissues. The degree to which the connective tissue phase of a tissue equilibrated with inulin or thiosulfate at any time was considered equal to the equilibration in tendon at that time.

The connective tissue corrected spaces were calculated as follows:

For chloride: The water associated with connective tissue was calculated and the amount of chloride present in this water (at a concentration equal to that in tendon)

\footnotetext{
${ }^{5}$ In measurements involving the whole body, the rapidly equilibrating water includes to some extent such water as is present in the gastrointestinal tract, in the cerebrospinal fluid, and in the lumina of exocrine glands.
} 
was subtracted from the total amount of chloride present in the tissue. The remainder of the chloride was divided by the concentration of chloride in an ultrafiltrate of plasma to give the combined volume of plasma water and rapidly equilibrating water. The sum of the plasma water, rapidly equilibrating water, and connective tissue water constitute the connective-tissue-corrected chloride space.

For inulin or thiosulfate: That fraction of the connective tissue water which was unpenetrated by inulin or thiosulfate (as defined by the penetration of tendon water at the identical time) was added to the measured inulin or thiosulfate space to give the connective-tissue-corrected inulin or thiosulfate space.

The volumes of distribution for inulin and thiosulfate in the whole body were calculated by dividing the total amount of the substance given, by the plasma water concentration at each hour. This calculated space in liters of water was expressed as per cent of body weight at zero, three and six hours. The zero hour plasma levels were obtained by extrapolation from the plasma concentration curves-for thiosulfate between the first and third hours, for inulin between the third and fifth hours.

\section{RESULTS}

The averages of the analyses on the animals are presented in Table $\mathrm{I}$, in terms of concentration $/ \mathrm{Kg}$. both of fat-free tissue and of water of fat-free tissue.

Figure 2 compares the size of the chloride space in muscle, tendon and skin water: The values used in the figure were calculated from the average of the three- and six-hour specimens of tissue. In the tendon it will be noted that the chloride space is represented as occupying more than a kilogram

TABLE I

Average tissue and serum values of eight nephrectomized dogs

\begin{tabular}{|c|c|c|c|c|c|c|c|c|c|c|c|c|c|c|c|}
\hline \multirow{2}{*}{ Tissue } & \multicolumn{8}{|c|}{ Values/Kg. fat-free tissue } & \multicolumn{7}{|c|}{ Values $/ \mathrm{Kg}$. fat-free tissue water } \\
\hline & $\mathrm{Na}$ & $\mathbf{K}$ & $\mathrm{Cl}$ & $\mathrm{H}_{2} \mathrm{O}$ & Inulin* & Thio. & $\begin{array}{c}\text { Collagen } \\
\text { dry }\end{array}$ & Elastin & $\mathrm{Na}$ & $\mathbf{K}$ & $\mathrm{Cl}$ & \begin{tabular}{|} 
Inulin \\
space
\end{tabular} & \begin{tabular}{|l} 
Thio. \\
space
\end{tabular} & $\begin{array}{l}\text { Collagen } \\
\mathrm{H}_{2} \mathrm{O}\end{array}$ & $\underset{\mathrm{H}_{\mathbf{8}} \mathrm{O}}{\text { Elastin }}$ \\
\hline $\begin{array}{l}\text { Control } \\
\text { Muscle }\end{array}$ & $\begin{array}{c}m E q . \\
29.3\end{array}$ & $\begin{array}{l}m E q . \\
81.6\end{array}$ & $\begin{array}{c}m E q . \\
20.1\end{array}$ & $\begin{array}{c}m l . \\
782\end{array}$ & $\begin{array}{c}G m . \\
0\end{array}$ & $\begin{array}{c}G m . \\
0\end{array}$ & $\begin{array}{l}\mathrm{Gm} . \\
23.7\end{array}$ & $\begin{array}{c}G m . \\
3.8\end{array}$ & $\begin{array}{c}m E q . \\
37.4\end{array}$ & $\begin{array}{r}m E q . \\
104.4\end{array}$ & $\begin{array}{c}m E q . \\
25.7\end{array}$ & $\begin{array}{c}m l . \\
0\end{array}$ & $\begin{array}{c}m l . \\
0\end{array}$ & $\begin{array}{l}m l . \\
66.4\end{array}$ & $\begin{array}{l}m l . \\
9.1\end{array}$ \\
\hline $3 \underset{\text { Mour }}{\text { Muscle }}$ & 31.7 & 78.6 & 19.9 & 776 & .1178 & .0954 & 24.4 & 4.5 & 40.9 & 101.4 & 25.6 & 109.7 & 140.2 & 68.8 & 10.8 \\
\hline $6 \underset{\text { Muscle }}{\text { Hourt }}$ & 25.6 & 90.2 & 15.6 & 770 & .0904 & .0566 & 10.3 & 4.1 & 33.3 & 117.1 & 20.3 & 96.1 & 101.7 & 29.3 & 10.0 \\
\hline $\begin{array}{l}\text { Control } \\
\text { Tendon }\end{array}$ & 97.8 & 13.7 & 85.9 & 667 & 0 & 0 & 300 & 12.8 & 146.5 & 20.5 & 128.8 & 0 & 0 & 964 & 36.0 \\
\hline $\begin{array}{l}3 \text { Hour } \\
\text { Tendon }\end{array}$ & 98.4 & 13.1 & 83.6 & 661 & .1558 & .2515 & 287 & 15.6 & 148.9 & 19.8 & 126.5 & 175.0 & 448.9 & 956 & 44.0 \\
\hline $6 \underset{\text { Tour }}{\text { Tendon }}$ & 96.2 & 14.2 & 86.4 & 662 & .2338 & .3710 & 292 & 8.1 & 145.3 & 21.4 & 130.6 & 269.3 & 767.5 & 977 & 23.0 \\
\hline $\begin{array}{l}\text { Control* } \\
\text { Skin }\end{array}$ & 97.2 & 20.6 & 87.4 & 748 & 0 & 0 & 148 & 24.1 & 130.0 & 27.6 & 116.8 & 0 & 0 & 433 & 60.2 \\
\hline $\begin{array}{l}3 \underset{\text { Hour }}{\text { Hkin }} \\
\text { Hon }\end{array}$ & $\mid 100.8$ & 22.2 & 85.7 & 741 & .4825 & .4630 & 164 & 26.6 & 136.0 & 29.9 & 115.6 & 478.5 & 776.6 & 484 & 67.4 \\
\hline $\begin{array}{l}6 \text { Hour* } \\
\text { Skin }\end{array}$ & 98.5 & 25.3 & 82.4 & 730 & .4640 & .3710 & 146 & 29.0 & 134.9 & 34.7 & 112.9 & 494.0 & 728.9 & 438 & 74.0 \\
\hline $\begin{array}{c}\text { Control } \\
\text { Serum }\end{array}$ & 148.1 & 3.73 & 112.2 & 944 & 0 & 0 & & & 156.8 & 3.95 & 118.8 & & & & \\
\hline $\begin{array}{l}3 \text { Hour } \\
\text { Serum }\end{array}$ & $\mid 156.9$ & 4.04 & 105.7 & 947 & \begin{tabular}{|l|l}
1.270
\end{tabular} & 0.887 & & & 165.7 & 4.27 & 111.7 & & & & \\
\hline $\begin{array}{l}6 \text { Hourt } \\
\text { Serum }\end{array}$ & \begin{tabular}{|l|l} 
& 156.7
\end{tabular} & 4.44 & 106.9 & 940 & $\mid 1.220$ & 0.721 & & & 166.8 & 4.72 & 113.8 & & & & \\
\hline
\end{tabular}

* Averages of 5 dogs.

+ Averages of 7 dogs.

$\ddagger$ Averages of 6 dogs. 


\section{THE ANATOMY OF \\ EXTRACELLULAR WATER}

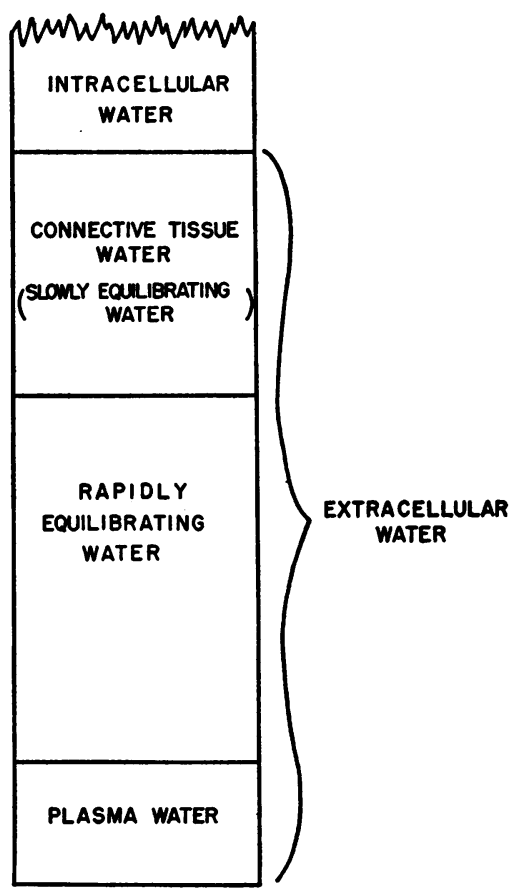

Fic. 1

of tendon water (112 per cent). This occurs because the concentration of chloride in tendon water was found to be greater than in a plasma ultrafil-

\section{THE CHLORIDE SPACE IN 1 KILO. OF TISSUE WATER}

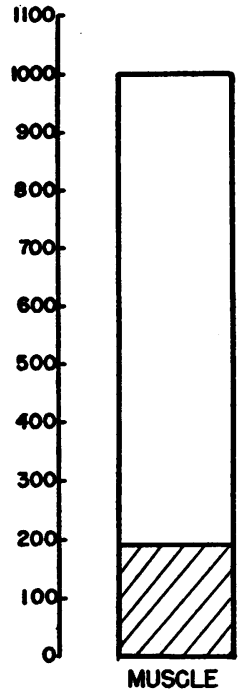

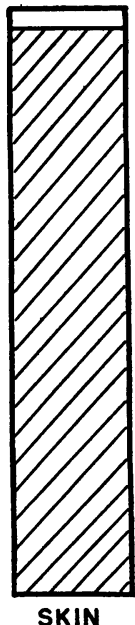

Fig. 2

trate. This has been reported previously by Manery, Danielson and Hastings (3).

Figure 3 illustrates the percentage penetration of the chloride space of the three tissues by thiosulfate and inulin at three and six hours.

\section{\% PENETRATION OF THE CHLORIDE SPACE}

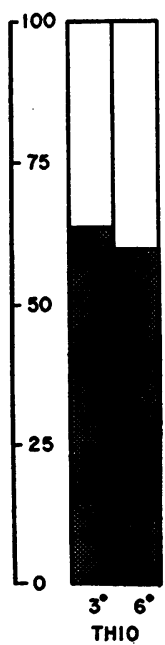

MUSCLE

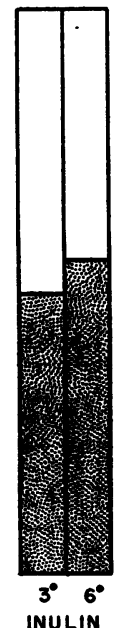

INULIN

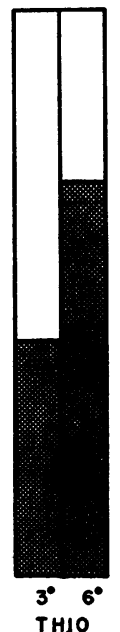

TENDON

Fig. 3
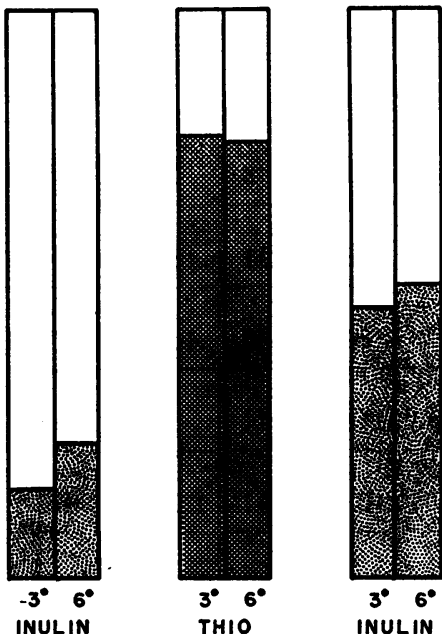

SKIN 
Three points are apparent from Figure 3 : First, in the time covered by these experiments neither thiosulfate nor inulin spaces in tissues reached the size of the chloride space. Second, thiosulfate appeared to penetrate tissues more rapidly than inulin. At both three and six hours, the thiosulfate space was larger than the inulin space. Third, in all of the tissues examined, the inulin space increased with time, whereas the thiosulfate space, although increasing in tendon, decreased in muscle and skin. This suggests that thiosulfate was broken down more rapidly in these tissues than in tendon, and that the rate of breakdown was sufficiently great to prevent the establishment of diffusion equilibrium between plasma water and the water of muscle and skin. In vitro experiments with muscle and tendon confirmed the fact that thiosulfate is destroyed by tissues rich in cells (7).

Figures 4 and 5 represent a kilogram of muscle and skin water at six hours and compare the results of various methods of measuring the extracellular phase water. These figures were constructed by first plotting the measured inulin space. The connective tissue water was superimposed in such a way that the portion penetrated by inulin (as calculated by the penetration of tendon at six hours) lay within the inulin space. The unpenetrated connective tissue water was placed above the inulin space. The water of the inulin space which was not connective tissue water was labelled "rapidly equilibrating water" and was assumed to be a plasma ultrafiltrate. Thus the rapidly equilibrating water plus the connective tissue water and the plasma water define an extracellular phase which has been termed the "Connective-TissueCorrected Inulin Space." In each case it will be noted that this estimate of extracellular water is smaller than the conventionally used chloride space. However, when the chloride space is corrected for the higher concentration of chloride which exists in collagen water as compared with plasma ultrafiltrate (i.e., the Connective-TissueCorrected Chloride Space), the space defined by chloride becomes smaller and more nearly approaches the Connective-Tissue-Corrected Inulin Space.

Figure 6 shows the average whole body thiosulfate and inulin spaces at zero, three and six hours expressed as per cent of total body weight. At zero time the inulin space is 17 per cent and

\section{KG. MUSCLE WATER}

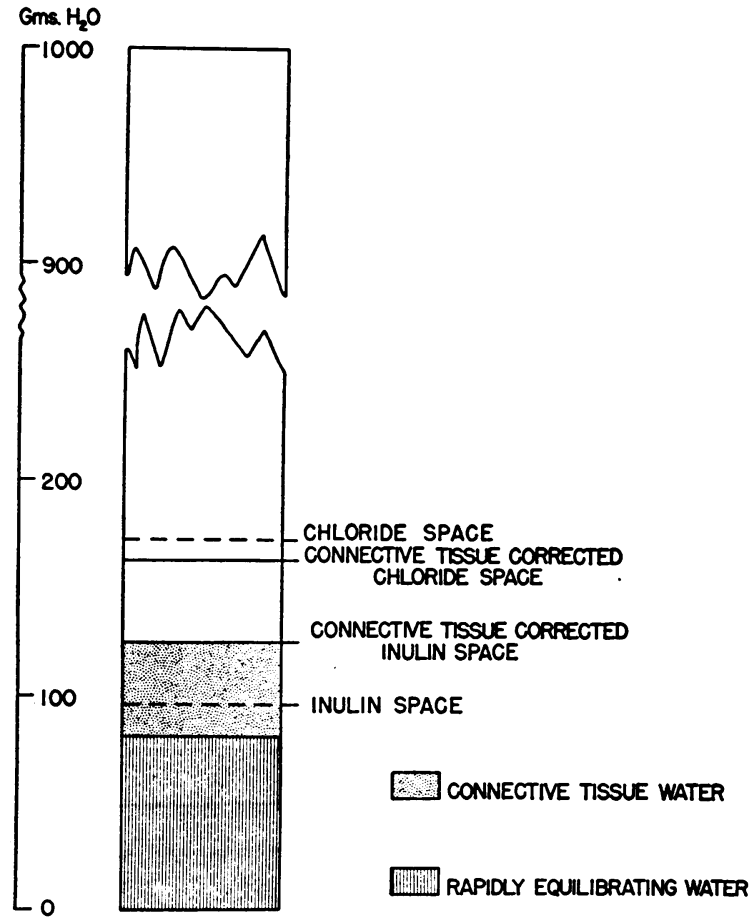

FIG. 4

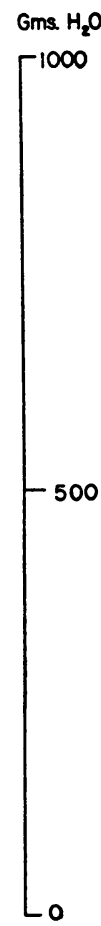

\section{KG. SKIN WATER}

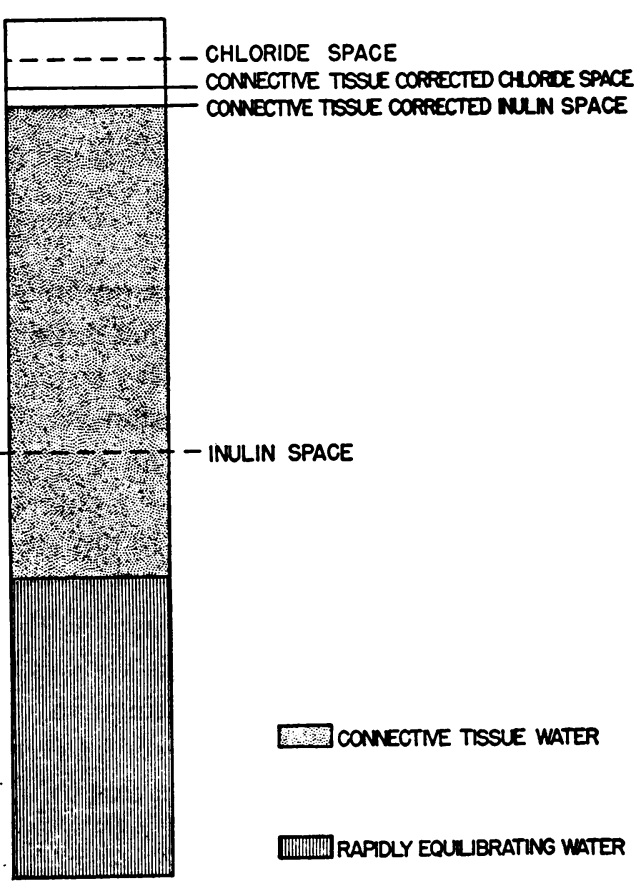

FIG. 5 


\section{- COMPARISON OF \\ INULIN AND THIOSULFATE SPACES}

IN WHOLE BODY -

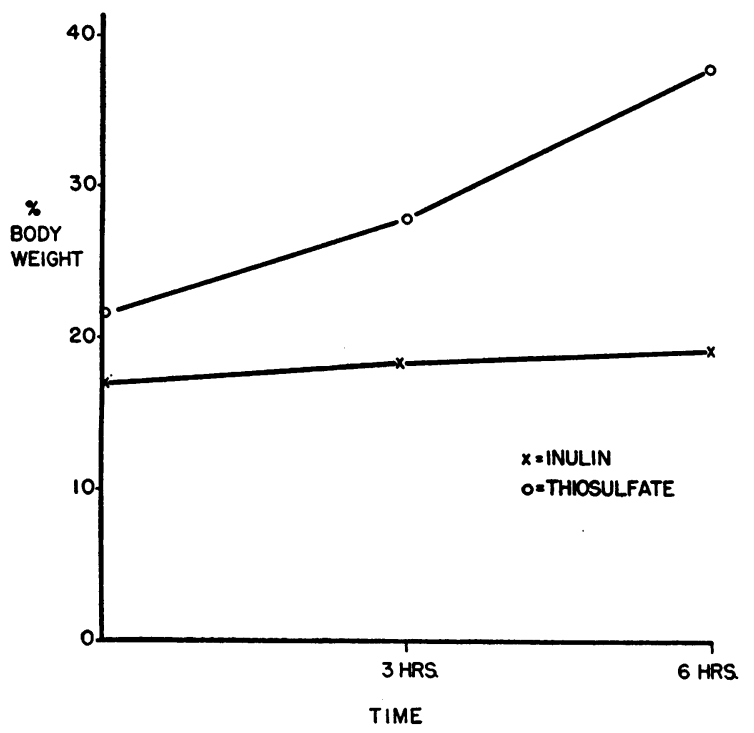

FIg. 6

the thiosulfate space 21.5 per cent; both increase with time. These values agree well with the results of other workers $(14,15,16)$. The increase in the inulin space in six hours is small-amounting to 2 per cent of the body weight; on the other hand, the increase in thiosulfate space in the same period of time amounts to 16 per cent of body weight.

\section{DISCUSSION}

In the development of the data presented in this communication, a number of assumptions have been made, the validity of which may be open to question. The analysis of tendon has been assumed to be representative of all connective tissue in the body-the higher water content of tissues such as skin being assumed to represent larger amounts of rapidly equilibrating water rather than a different form of collagenous tissue with a higher water content. In support of this view is the work of Manery, Danielson and Hastings in which the water and electrolyte content of fat-free tendon was found to be identical with that of perirenal areolar tissue after fat removal (3). It has also been assumed that the penetration of tendon water by inulin or thiosulfate should reflect the pene- tration of all body connective tissue by these substances. Although identity in chemical composition does not necessarily impose identity in the rate of penetration by a foreign substance, the data reported here are in accord with this assumption.

The plasma disappearance curves of injected foreign substances such as inulin and thiosulfate are determined by several factors-urinary excretion, mixing through the plasma, diffusion into various components of the extracellular compartment, diffusion into body cavities and hollow viscera, and metabolic breakdown. At least two rates of disappearance are apparent from the work of Cotlove with inulin (17).

There is first a rapid rate with a half time of less than 30 minutes which probably represents mixing in the plasma and equilibration with a volume of water outside the vascular bed which reaches rapid equilibrium with plasma. The volume defined by this first rapid component probably represents the plasma and rapidly equilibrating water as defined above. The second component of the disappearance curve is very much slower, with a half time of about 10 hours. This part of the curve is usually assumed to represent equilibrium between plasma and extracellular fluid. The very slow decline of concentration that occurs in this later period is generally assigned to metabolic breakdown, pathologic shifts of water, or intracellular penetration of the substance being studied (14), but, as will be discussed, it probably represents equilibration between connective tissue water and the rest of the extracellular water. The zero hour value is extrapolated from this second component of the curve. In reality, this extrapolated value defines only the plasma and rapidly equilibrating water at a time when no connective tissue water has been penetrated.

Figure 7 shows that the slow disappearance rate of inulin can be entirely accounted for on the basis of diffusion into connective tissue water during the six hours of these experiments. This figure demonstrates the relationship between the increase with time in the inulin space of the total body and the increasing penetration of connective tissue water. The diagram is composed of four pairs of columns. The right-hand column of each pair represents the measured inulin space of a kilogram of whole body. The left-hand column is the connective-tissue-corrected inulin space of 
whole body, which is seen to be composed of plasma water, rapidly equilibrating water and connective tissue water. At zero hours it is assumed that inulin has not penetrated any of the connective tissue water, and therefore defines only the plasma and rapidly equilibrating water (170 $\mathrm{ml}$. per $\mathrm{Kg}$. of whole body). The connective tissue water $(77 \mathrm{ml}$. per $\mathrm{Kg}$.) was calculated from Lightfoot and Coolidge's measurements of total body collagen (18) and our data on tendon water. The sum of plasma. water, rapidly equilibrating water, and connective tissue water (or the connective-tissue-corrected inulin space) is $247 \mathrm{ml}$. per $\mathrm{Kg}$. of body, and is represented by the dotted line. This figure is seen to be almost identical with figures given by other workers for the whole body chloride space $(19,20)$, which is represented by a dashed line.

At three hours the measured whole body inulin space is $184 \mathrm{ml}$. per $\mathrm{Kg}$. of body-an increase of $14 \mathrm{ml}$. per $\mathrm{Kg}$. If this increase is exclusively due to penetration of the connective tissue water, it should be equal to the product of the per cent penetration of tendon water (17.5 per cent) and the calculated amount of total body collagen water (77 ml. per $\mathrm{Kg}$.). When this is calculated, a figure of $13.5 \mathrm{ml}$. is obtained. This, added to the rapidly equilibrating water plus plasma water, gives a calculated inulin space of $183.5 \mathrm{ml}$. This figure, indicated by the arrow, is almost identical with the measured value at this time $(184 \mathrm{ml})$. In the diagram the fraction of connective tissue water penetrated by inulin is indicated by the crosshatched area.

At six hours, when the measured inulin space is $191 \mathrm{ml}$, the tendon penetration is 27 per cent or $21 \mathrm{ml}$. of connective tissue water; the calculated inulin space (indicated by the arrow) is $191 \mathrm{ml}$.identical with the measured one.

The last set of columns represents the situation at an hypothetical time (X), in excess of 24 hours, when all of the connective tissue water has been penetrated (assuming no inulin to have been destroyed by metabolic processes). The measured inulin space would therefore be equal to the connective-tissue-corrected inulin space (there being no unpenetrated connective tissue water at this time).

The studies reported here were not of sufficient duration to provide data concerning the relative sizes of the inulin and chloride spaces at 24 hours or later. Cotlove has shown that, in rats receiving a constant infusion of inulin, the inulin space in muscle continues to approach the chloride space, representing 95 per cent of it at 24 hours (17). This agrees well with the hypothesis that the in-

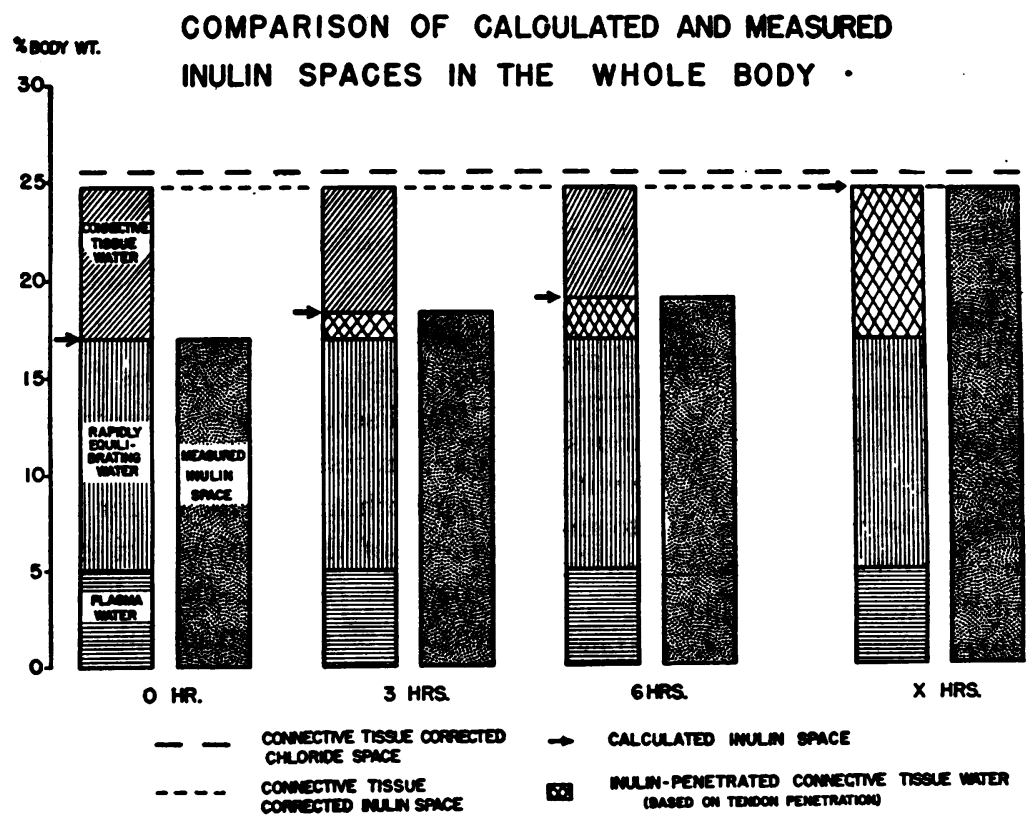

FIG. 7 
crease in the inulin space with time is due to increased penetration of connective tissue. However, Finkenstaedt, O'Meara, and Merrill (21), studying the volume distribution of a single injection of inulin in anuric animals and human subjects over a period of 24 to 96 hours, showed that the inulin space increased progressively and in some cases reached a volume distribution equal to that of total body water. Other investigators were unable to recover more than 50 per cent of administered inulin in oliguric and edematous patients (22). These data suggest that inulin is metabolized in the body. In view of Cotlove's data, the rate of metabolism must be very slow, and during the six hours of the experiments described herein must have been negligible. However, it is unlikely that complete penetration of tendon water, as shown in Figure 7, ever occurs, since, by the time this state is reached, significant amounts of the injected inulin have probably been metabolized.

The increase in the thiosulfate space cannot be accounted for by increased penetration of connective tissue alone. It will be seen from Figure 7 that at zero hours the thiosulfate space is 21.5 per cent of the total body weight. By three hours the space is 27.8 per cent or $278 \mathrm{ml}$. per $\mathrm{Kg}$. and exceeds the extracellular space as measured by either chloride or the connective-tissue-corrected inulin space. By six hours the space is 37.6 per cent. Since tendon is incompletely penetrated by thiosulfate at both three and six hours, correction for the unpenetrated water would further increase the space, which is already larger than is compatible with any known data. Moreover, in muscle and skin the six-hour space is actually smaller than it is at three hours, and at no time does the thiosulfate space equal the chloride space in any tissue, in spite of the fact that in whole body the thiosulfate space is larger than the chloride space at three hours and increases still further at six hours. Therefore, the increase in the thiosulfate space with time in the whole body must in part be due to increasing penetration of connective tissue and in part to destruction of thiosulfate $(16,23)$.

Despite small differences in electrolyte pattern, connective tissue water is similar to a plasma ultrafiltrate and distinctly different in chemical composition from intracellular water as exemplified by the analysis of highly cellular tissues such as muscle. Since, morphologically, connective tissue is largely made up of collagen and elastin fibers and very few cells, it seems more logical, as suggested by Manery, Danielson, and Hastings (3), to consider such tissues as part of the extracellular phase of the body than to arbitrarily assign them to the cellular compartment. Experimental alterations of plasma electrolyte concentrations appear to be accompanied by similar changes in the electrolyte concentrations in connective tissue water (24-26). One interpretation of these data is that the ions of connective tissue are in diffusion equilibrium with plasma, unlike the relationship which exists between muscle cells and extracellular fluid. However, more complete and conclusive data must be obtained before this equilibrium becomes accurately defined. The relationship between the total extracellular fluid as defined here and the rapidly equilibrating, physiologically active water may vary with time, with changes in acid-base balance, endocrine status, and with the state of hydration of the individual.

From the foregoing data, it would appear that a definite division of tissue water into extra- and intracellular phases cannot be made on the basis of an inulin, thiosulfate or chloride determination alone. In the nonedematous animal, the discrepancy between the extracellular phase and the space defined by a large molecule such as inulin appears to be due to the relatively slow penetration of connective tissue by this material; in the case of thiosulfate it is in part due to this slow penetration and in part due to the breakdown in tissues.

Although the incomplete penetration of connective tissue by inulin and thiosulfate makes only a small difference in the analysis of selected muscle samples (Figure 4), when applied to tissues such as skin or to the whole body the error becomes considerable (see Figures 5 and 7).

The discrepancy between the chloride and inulin spaces in tissue samples can be largely eliminated when both are corrected for the connective tissues content of the sample. If it is assumed that the connective-tissue-corrected inulin space is the true measure of the extracellular space, the remaining difference, which amounts to 1 to 3 per cent of the tissue, may represent either intracellular chloride at a concentration of less than five $\mathrm{mEq}$. per $\mathrm{L}$. of intracellular fluid, red cell chloride, or analytic error. Thus, either the connective-tissue-corrected 
inulin space or the connective-tissue-corrected chloride space represents the best available estimate of extracellular water in individual tissues.

Both of these measurements require a knowledge of the connective tissue content of the material under study. In the case of tissue biopsies this is easily obtained; but in the whole body it is obviously impossible, although estimates are available from the carcass analysis of normal animals. While such estimates may be suitable for normals, they may be grossly in error in certain pathologic states. However, since the correction of the chloride space for the connective tissue in the whole body and for the chloride known to be present in red cells, gastric mucosa, testis, and exocrine secretions is much smaller than that required for the inulin space and further does not vary with time, the chloride space appears to be the most useful measure of the extracellular space of the whole body.

\section{SUMMARY AND CONCLUSIONS}

1. The distribution of inulin and thiosulfate has been studied simultaneously in the tissues and whole bodies of eight nephrectomized dogs and correlated with the chloride and connective tissue content of tissues.

2. In all tissues studied the chloride space exceeded the inulin and thiosulfate spaces throughout the period of study (six hours).

3. When the chloride and inulin spaces of tissues were corrected for the connective tissue content of the samples, these spaces were in close agreement.

4. In the whole body both inulin and thiosulfate spaces increased with time. The increase in the inulin space could be accounted for by the increasing penetration of connective tissue; the increase in the thiosulfate space was far greater than could be accounted for by the penetration of connective tissue, and must have been due to the destruction of this substance by cellular tissues.

5. Evidence is presented to indicate that the extracellular fluid consists of two phases: one, the total phase, measured by chloride, and a second, smaller, and probably physiologically more active one, measured by the volume distribution of large molecules such as inulin.

\section{ACKNOWLEDGMENT}

The authors gratefully acknowledge the technical assistance of Miss Antoinette de Simone.

\section{REFERENCES}

1. Wallace, W. M., Some aspects of the chemical composition, physiology, and pathology of intracellular fluid. Pediatrics, 1952, 9, 141.

2. Kruh $\phi$ ffer, P., Inulin as indicator for extracellular space. Acta physiol. Scandinav., 1946, 11, 16.

3. Manery, J. F., Danielson, I. S., and Hastings, A. B., Connective tissue electrolytes. J. Biol. Chem., 1938, 124, 359.

4. Lowry, O. H., and Hastings, A. B., Histochemical changes associated with aging: I. Methods and calculations. J. Biol. Chem., 1942, 143, 257.

5. Berry, T. W., Chappell, D. G., and Barnes, R. B., Improved method of flame photometry. Indust. \& Engin. Chem. (Analyt. Ed.), 1946, 18, 19.

6. Wilson, D. W., and Ball, E. G., A study of the estimation of chloride in blood and serum. J. Biol. Chem., 1928, 79, 221.

7. Nichols, G., and Nichols, N., Unpublished data.

8. Newman, E. V., Gilman, A., and Philips, F. S., Renal clearance of thiosulfate in man. Bull. Johns Hopkins Hosp., 1946, 79, 229.

9. Lowry, O. H., Gilligan, D. R., and Katersky, E. M., The determination of collagen and elastin in tissues, with results obtained in various normal tissues from different species. J. Biol. Chem., 1941, 139, 795.

10. Ross, G., and Mokotoff, R., Determination of inulin in muscle. J. Biol. Chem., 1951, 190, 659.

11. Weil, W. B., Preparation of a stable form of inulin for tissue analysis. Proc. Soc. Exper. Biol. \& Med., 1952, 80, 103.

12. Van Slyke, D. D., and Hiller, A., Application of Sendroy's iodometric chloride titration to proteincontaining fluids. J. Biol. Chem., 1947, 167, 107.

13. Roe, J. H., Epstein, J. H., and Goldstein, N. P., A photometric method for the determination of inulin in plasma and urine. J. Biol. Chem., 1949, 178, 839.

14. Gaudino, M., and Levitt, M. F., Inulin space as a measure of extracellular fluid. Am. J. Physiol., 1949, 157, 387.

15. Schwartz, I. L., Schachter, D., and Freinkel, N., The measurement of extracellular fluid in man by means of a constant infusion technique. J. Clin. Invest., 1949, 28, 1117.

16. Cardozo, R. H., and Edelman, I. S., The volume distribution of sodium thiosulfate as a measure of the extracellular fluid space. J. Clin. Invest., 1952, 31, 280.

17. Cotlove, E., Inulin and chloride space in muscle. Federation Proc., 1952, 11, 28. 
18. Lightfoot, L. H., and Coolidge, T. B., The distribution of collagen in the guinea pig. J. Biol. Chem., 1948, 176, 477.

19. Winkler, A. W., Elkinton, J. R., and Eisenman, A. J., Comparison of sulfocyanate with radioactive chloride and sodium in the measurement of extracellular fluid. Am. J. Physiol., 1943, 139, 239.

20. Harrison, H. E., Darrow, D. C., and Yannet, H., The total electrolyte content of animals and its probable relation to the distribution of body water. J. Biol. Chem., 1936, 113, 515.

21. Finkenstaedt, J. T., O'Meara, M. P., and Merrill, J. P., Failure of equilibration of inulin in anuric subjects. J. Clin. Invest., 1952, 31, 627.

22. Last, J. H., Jones, R. A., McDonald, G. O., and Bond, E. E., Failure to quantitatively account for infused inulin in human subjects. Federation Proc., 1952, 11, 367.

23. Gilman, A., Philips, F. S., and Koelle, E. S., The renal clearance of thiosulfate with observations on its volume distribution. Am. J. Physiol., 1946, 146, 348.

24. Muntwyler, E., Mellors, R. C., Mauntz, F. R., and Mangun, G. H., Electrolyte and water equilibrium in the dog. III. Electrolyte and water exchange between tendon and blood. J. Biol. Chem., 1940, 134, 389.

25. Amberson, W. R., Nash, T. P., Mulder, A. G., and Binns, D., The relationship between tissue chloride and plasma chloride. Am. J. Physiol., 1938, 122, 224.

26. Nichols, N., Unpublished data. 